\title{
THEIR LABYRINTH MOUTHS OF HISTORY
}

\author{
MARCELA SULAK \\ Bar-Ilan University
}

\begin{abstract}
This paper outlines reading strategies to help map Hart Crane's book-length poem, The Bridge, as a repository of American runes and writing. Contextualizing the poem in the philosophical, historical, and popular culture that influenced its creation, we can examine Hart Crane's linguistic condensation, puns, and etymological play as techniques for balancing the clash between eternity and secular history upon which America was founded, rehearsed in The Bridge in the clash between secular a-temporality and the historical moment.
\end{abstract}

Keywords: Hart Crane, The Bridge, American Poetry, Brooklyn Bridge, John Roebling, Josef Stella, Myth of America, Mikhail Bakhtin

Time was invented so that everything wouldn't always happen at once. Space was invented so that everything wouldn't always happen to me.

--paraphrase of Albert Einstein and Garrison Keillor

And through that cordage, threading with its call

One arc synoptic of all tides below-

Their labyrinthine mouths of history

Pouring reply as though all ships at sea

Complighted in one vibrant breath made cry,-

"Make thy love sure- to weave whose song we ply!"

Hart Crane - Atlantis

Reading Hart Crane's Bridge can be like plunging into an etymological dictionary; it can be like landing on a four-dimensional map of the present, past, and future, all at once. The purpose of this paper is to outline a few reading strategies to help navigate this book as a repository of American runes and writing.

This book-length serial poem in 14 sections, which took over ten years to write, was published in 1929 in Paris, and then 1930 in New York, stymied nearly everyone. It was Crane’s attempt to write “The Myth of America” for a 
country that was created too recently to have forgotten or mythologized its past. A sophisticated high modernist design and aesthetic inflects this largely romantic endeavor; its spiritual ambitions had the financial backing of the banker Otto Kahn-and while the dissonances certainly perform the contradictions inherent in the project of America, the public was not quite prepared for them.

The eponymous Brooklyn Bridge itself, as a physical structure, referenced the sublime religious architecture of medieval Europe, with the arches of its columns, but it was made possible by ultra-new technology. It was the first bridge created using steel cables, which allowed for exponentially longer bridges than iron did. It was engineered by John Roebling, a student of Hegel, who saw that America was the current home of the spirit of history. The bridge was viewed by Roebling, as well as by the Mayor of Brooklyn, and by Hart Crane, as the final leg that completed the failed voyage of Columbus to circumnavigate the globe (Steinman 21; Trachtenberg, Brooklyn Bridge, 76).

The image of Joseph Stella's Bridge that served as the frontispiece is a visual representation of Crane's poem, and a sort of guide to reading the book, just as the painting's cross hatching reproduces an image of the Bridge across the city's architecture, drawing everything together into what Stella calls "the convergence of worlds," even the buildings (in Stella's image) that had not yet been built. Hold this in mind (Knox 696).

The preamble to the poem contains all the techniques and strategies that are later repeated in a different way throughout the remaining sections of the poem. Any part of the poem quoted in this paper can be found in the poem below, unless otherwise noted.

To Brooklyn Bridge

How many dawns, chill from his rippling rest

The seagull's wings shall dip and pivot him,

Shedding white rings of tumult, building high

Over the chained bay waters Liberty-

Then, with inviolate curve, forsake our eyes

As apparitional as sails that cross

Some page of figures to be filed away;

— Till elevators drop us from our day ...

I think of cinemas, panoramic sleights

With multitudes bent toward some flashing scene

Never disclosed, but hastened to again,

Foretold to other eyes on the same screen;

And Thee, across the harbor, silver paced 
As though the sun took step of thee yet left Some motion ever unspent in thy stride,Implicitly thy freedom staying thee!

Out of some subway scuttle, cell or loft A bedlamite speeds to thy parapets, Tilting there momently, shrill shirt ballooning, A jest falls from the speechless caravan.

Down Wall, from girder into street noon leaks, A rip-tooth of the sky's acetylene;

All afternoon the cloud flown derricks turn ...

Thy cables breathe the North Atlantic still.

And obscure as that heaven of the Jews, Thy guerdon ... Accolade thou dost bestow Of anonymity time cannot raise:

Vibrant reprieve and pardon thou dost show.

O harp and altar, of the fury fused, (How could mere toil align thy choiring strings!

Terrific threshold of the prophet's pledge, Prayer of pariah, and the lover's cry,

Again the traffic lights that skim thy swift Unfractioned idiom, immaculate sigh of stars, Beading thy path-condense eternity:

And we have seen night lifted in thine arms.

Under thy shadow by the piers I waited

Only in darkness is thy shadow clear.

The City's fiery parcels all undone, Already snow submerges an iron year ...

O Sleepless as the river under thee, Vaulting the sea, the prairies' dreaming sod, Unto us lowliest sometime sweep, descend And of the curveship lend a myth to God (Complete poems, 45-46).

From the very beginning, this poem teases out Crane's belief in an America conceived through two contradictory impulses-commercialism and spiritualism. Columbus's voyage was funded by Isabelle and Ferdinand in Spain. Isabelle was eager to discover new worlds so as to convert souls to Christianity. Ferdinand was eager to discover gold, silver, and other raw materials to enrich his kingdom. Thus, the entire poem is constructed upon, and 
energized by, the tension between these two poles: spirituality, eternity, and the concept of "absolute time" or "the fullness of time," that Crane borrowed from the Russian esotericist P.D. Ouspensky, in which everything already exists all at once (, and capitalism, which represents the contemporary moment, and here, Crane reads each moment of history as if it were occurring in its own contemporary moment. ${ }^{1}$

Crane's use of metonyms and synecdoche connects the historical moments of American history through a proliferation of bridge figures and bridge verbs. so that the Brooklyn Bridge (the poems' present moment) is always already present-in the arc of Columbus's sails, in the wings of sea gulls which appear at various moments in the poem, and anything at all that is curved in the poem (such as smiles, rainbows, and other phenomena). As Crane wrote to his friend Waldo Frank on Jan 18, 1926, "The bridge in becoming a ship, a world, a woman, a tremendous harp (as it does finally) seems to really have a career!" (OMLMF 226-7). The bridge is most commonly referred to by its shape, which is an arc. The arc becomes the sails of Columbus's ship in "Ave Maria," and sea gull wings in "To Brooklyn Bridge," the smile of the pioneer and squaw women in "Indiana," and a harp (which creates celestial music) in "Atlantis." The harp image works especially well because it refers to the "choiring strings" of the Bridge's cables, allowing power lines, radio waves and train tracks ("The River"), power lines (“Cape Hatteras"), and traffic lights ("Atlantis") to act as metonyms for the harp/bridge as well. These incarnations of the bridge represent particular moments in history: Columbus's voyage, the Native American period, various revolutionary voyages and discoveries, and finally, the completion of the Bridge

In order to see how the Bridge as harp or accolade turns all sound into musical notes that sound on the harp/bridge (in this way, the bridge stays in one place, but travels through time and space) one needs to recognize both puns and secondary and tertiary meanings of words. The puns work by mixing temporalities, mixing movement and speech and multiple etymological meanings which allow one sentence with a single noun and a single verb to split into various subjects and various predicates, causing simultaneous actions in time and space. One example in the passage quoted above is:

As apparitional as sails that cross

Some page of figures to be filed away

If the word "sails" were spelled "sales" the entire line would refer to present-day shopping. If you are listening to the poem, there is no way to distinguish the two

\footnotetext{
${ }^{1}$ Crane's choice of founding moments is remarkably close to that those of William Carlos Williams', whose 1925 In The American Grain argued against the Anglo-centric view of earlier English-language writers in America.
} 
spellings. Since all the other figures are symbols and metonyms for the Bridge, it follows that all speech belongs to the Bridge itself. Indeed, one of the most powerful images of the Bridge is that of an "accolade," a brace or a line used in music to join two or more staffs carrying simultaneous instrumental or voice parts. Thus, all speech and silence belongs to the Bridge's "unfractured idiom.”

The poem's many idioms found in the fourteen sections include, among many others, colloquial dialects ("Van Winkel" 58-62, "The River" 62-69, "Indiana" 76-79, “Cutty Sark" 81-85, "The Tunnel” 107-114) detergent and toothpaste ads ("The River" 62-69), lofty prayers to the Madre Maria ("Ave Maria” 47-52) and eloquent petitions to Walt Whitman (“Cape Hatteras” 87-95) elegiac odes to Edgar Allen Poe ("The Tunnel” 107-114) and sounds (voices of the living and the dead, wordless sighs and half-heard sobs, mechanical noises clothed in fog ("Harbor Dawn" 54-56, among others) juke boxes ("Cutty Sark" 81-85), hurdy-gurdies ("Van Winkel" 58-62) are transmitted by radio waves, railroad ties (which sing; also, the train-riding hoboes sing, as do the road gangs they meet), by the cipher of the biplanes the river, the sea, and also by the speech of the poem's characters.

Even actions are turned into speech or sounds, as we can see in "To Brooklyn Bridge" produced in full at the beginning of this paper: the "bedlamite" that "speeds to thy parapets" to leap into time and eternity wears a ballooning shirt that is "shrill." In response the "caravan" below (the spectators) is speechless, but it lets fall a "jest" or gesture. ${ }^{2}$ Responding to the act of annihilation, with a speechless action, has turned into speech (a "jest"). The "caravan" emerges in the next section, "Ave Maria" (47-52) as a "caraval" where the " silent crowd" perhaps becomes the "kindled Crown." Likewise, the footprints left by God in "To the Brooklyn Bridge" become, in "Ave Maria" swirling chords that sound: "The orbic wake of thy once whirling feet, / Elohim, still I hear thy sounding heel!" (51). The narrator's tongue on the throat of his beloved is "singing." The choiring cables reach from the Ganges to the East River, from Eden to Kitty Hawk, from the subway tunnels below the earth to the morning star, transforming all speed and movement into sound, all sound into a "multitudinous Verb." ${ }^{3}$ There is much evidence that the language of the poem is meant to be some divine speech, unspeakable in human language, that is able to "lend a myth to God;" it is the "incognizable Word/ Of Eden and the enchained Sepulchre" in "Ave Maria" (51). This is in keeping with the rhetoric surrounding the creation of the physical Bridge, which inspired comparisons

\footnotetext{
${ }^{2}$ Signifying a crowd with the word "caravan" inscribes the group into the movement of peoples across a land.

${ }^{3}$ A similar pattern occurs when you trace the use of "sight" "eyes" and "vision." Also, words clustering around the concept of sleep and wakefulness seem to parallel those clustering around sight and blindness.
} 
with the work of the Almighty. Councilman Abram S. Hewitt said, at the opening ceremonies, May 24, 1883,

\begin{abstract}
When we turn to the graceful structure at whose portal we stand, and when the airy outline of its curves of beauty, pendent between massive towers suggestive of art alone, is contrasted with the over-reaching vault of heaven above and the evermoving flood of waters beneath, we are irresistibly moved to exclaim, 'What hath man wrought!'...But the Bridge is more than an embodiment of the scientific knowledge of physical laws. It is equally a monument to the moral qualities of the human soul. It could never have been built by mere knowledge alone [italics in original].(qtd. in Steinman 413)
\end{abstract}

This phrase, among others surrounding the creation of the Brooklyn Bridge, is echoed in "To Brooklyn Bridge" above, embraced by a pair of parentheses, little arches themselves,: "(How could mere toil align thy choiring strings!)"

The use of the arc throughout the poem as the symbol for the Bridge comes from Ouspensky, whom Crane read throughout the 1920s: "In reality, the circle of life is only the section of something, and that something undoubtedly exists before birth, e.g., before the appearance of the circle in our space, and continues to exist after death, i.e., after the disappearance of the circle from the field of our vision" (105). Thus, the arc (only part of a full circle) of the Brooklyn Bridge is the shape in which "time takes on flesh" and "becomes visible" in Crane's 1920s New York.

This resonantes with Stella's commentary on the completeness of a work of art, pointing to the central conflict of the poem, which can be framed as an openended dialogue:

When we think that our epoch, like every other epoch is nothing else but a point in the immensity of time, we have to laugh [at] those standards that people considered eternal. The masterpiece--a Phrase of the infinite speech running through the centuries can't be the final word it is supposed to be. You cannot consider a phrase no matter how perfect it is, complete and final when the whole sentence is not finished." (qtd. in Knox 696) ${ }^{4}$

To that end, The Bridge references various literary genres of past epochs: the

\footnotetext{
${ }^{4}$ Both Irma Jaffe and George Knox have written on the similarity of Crane and Stella's techniques. Knox attributes this similarity to the influence of the social and historical milieu, while Jaffe plays detective, trying to determine how and to what extent Crane could have been exposed to Stella in the course of his writing.
} 
epic, most notably in the battle scene rendered in hexameter in which the biplane challenges the sky in "Cape Hatteras;" the travelogue in "Ave Maria," for which Crane drew indirectly on Christopher Columbus's diary, apparently via William Carlos Williams's In the American Grain. "Indiana” is written in the form of a personal letter; "the River" and "Cutty Sark" are set to a jazz rhythm interrupted by billboard advertisements and juke-box music, respectively. "Harbor Dawn" is a love lyric, as is the little italicized poem that appears intermittently on the right facing page from "Ave Maria” to "Indiana.” “The Dance” is reminiscent of the dream- visionary. In borrowing elements of these genres, Crane constructs a poem in the same way that the architects and city planners constructed New York at the time: by recycling elements of the past and recombining them in order to "make it new," as Ezra Pound had commanded. Each of the genres to which Crane alludes contains, in Bakhtin's words, "a congealed old world view." As Emerson and Morson put it, this way "a genre remembers past experience. That is, genres contain a vast storehouse of experiential wisdom of which we are often unaware, but which can be partially reconstructed under the pressure of new experiences" (MB, 290-291). These congealed worldviews, with their particular configurations of time and space, of which images and genres are short-hand expressions, are also in dialogue with the dominant composite chronotope of The Bridge. Bakhtin calls these "intervallic" chronotopes because they occur in intervals that "interrupt and shed light on the chronotope of the main narrative" (CP 404). In addition to providing subplots (as in the The Bridge's story of Rip Van Winkle, or the italicized love lyric on the right-hand facing page of the first four sections), they highlight "the possibility of viewing action from two different chronotopic perspectives" and "the fact that each chronotope is one of many possible chronotopes” (CP 404).

In borrowing elements of these genres, Crane constructs a poem in the same way that the architects and city planners constructed New York at the time: by recycling elements of the past and recombining them in order to "make it new," as Ezra Pound had commanded.

Crane sometimes expressed doubts about the worthiness of the project, not because the poem itself was flawed, but because the present was not worthy of its past:

...The bridge as a symbol today has no significance beyond an economical approach to shorter hours, quicker lunches, behaviorism and toothpicks (Letter to ToWaldo Frank, Isle of Pines, Cuba, June 20, 1926). (OMLMF 258-9).

However, instead of suppressing this doubt for the purposes of presenting a seamless monologue, Crane works subversively, allowing the commercialism of the present to speak for itself in its own voice. Thus, he "reveals the limits" of 
his own construction of the myth of America, and of the present moment "as inadequate, imposed, or arbitrary” (OMLMF 259).

\section{References}

Bakhtin, M. M. The Dialogic Imagination. Four Essays. Ed. Michael Holquist. Trans. Caryl Emerson and Michael Holquist. Austin: University of Texas Press, 1981.

. "Discourse Typology in Prose." Readings in Russian Poetics: Formalist and Structuralist Views. Ed. Ladislas Matejka and Krytyna Pomorska (Cambridge: M.I.T. Press, 1971) 176-99.

. Speech Genres and Other Late Essays. Eds. Caryl Emerson and Michael

Holquist. Trans. Vern W. McGee. Austin: University of Texas Press, 1986

Crane, Hart. The Complete Poems and Selected Letters and Prose of Hart Crane. Ed. Brom Weber. New York: Doubleday, 1966.

.The Letters of Hart Crane 1916-1932. Ed. Brom Weber. New York: Hermitage House, 1952.

.O My Land, My Friends! The Selected Letters of Hart Crane. Ed. Langdon Hammer and Brom Weber. New York: Four Walls Eight Windows, 1977.

Giles, Paul. Hart Crane: The Contexts of The Bridge. Cambridge: Cambridge UP, 1986 Jaffe, Irma Blumenthal. Joseph Stella. Cambridge, MA: Harvard University Press, 1970.

"Joseph Stella and Hart Crane. The Brooklyn Bridge." American Art Journal 1 (Fall 1969) 98-107.

Knox, George. "Crane and Stella: Conjunctions of Painterly and Poetic Worlds." Texas Studies in Literature and Language 12:4 (Winter, 1971) 680-707.

Ouspensky, P. D. Tertium Organum. Trans. Nicholas Bessaraboff and Claude Bragdon. New York: Vintage Books, 1920.

Steinman, D. B. The Builders of the Bridge. New York: Harcourt, Brace and Company, 1945.

Trachtenberg, Alan. Brooklyn Bridge: Fact and Symbol. New York: Oxford University Press, 1965.

. "The Shadow of a Myth". Hart Crane. A Collection of Critical Essays. Ed. Alan Trachtenberg. Englewood Cliffs, N.J.: Prentice-Hall, Inc., 1982. 111130.

Wiliams, William Carlos. In the American Grain. New York: New Direction's Paperback. 1956.

\section{BIONOTE}

Marcela Sulak is the author of the lyric memoir Mouth Full of Seeds; her third poetry collection, City of Sky Papers is forthcoming with Black Lawrence Press, where she has previously published Decency and Immigrant. She has coedited Family Resemblance: An Anthology and Exploration of 8 Hybrid Literary Genres. A 2019 NEA Translation Fellow, her fourth translation, Twenty Girls to 
Envy Me. Selected Poems of Orit Gidali was nominated for a 2017 PEN Award for Poetry in Translation. She hosts the podcast "Israel in Translation," edits The Ilanot Review, and is Associate Professor of English Literature and Linguistics at Bar-Ilan University.

E-mail:.mmsulak@gmail.com 
